Article

\title{
Biofunctionalization of Textile Materials.1. Biofunctionalization of Poly(Propylene) (PP) Nonwovens Fabrics by Alafosfalin
}

\author{
Marcin H. Kudzin *, Zdzisława Mrozińska, Anetta Walawska and Jadwiga Sójka-Ledakowicz \\ Łukasiewicz Research Network-Textile Research Institute, Brzezińska 5/15, Lodz 92-103, Poland \\ * Correspondence: kudzin@iw.lodz.pl; Tel.: +48-42-616-3121
}

Received: 8 May 2019; Accepted: 17 June 2019; Published: 28 June 2019

\begin{abstract}
This paper presents the method of obtaining poly(propylene) (PP) nonwoven fabrics with antimicrobial properties, using Alafosfalin as the nonwoven modifying agent. Alafosfalin, namely L-alanyl-L-1-aminoethylphosphonic acid, presents representative P-terminal phosphonodipeptide, which possesses a strong, broad spectrum of antimicrobial properties. The analysis of these biofunctionalized nonwoven fabrics processed by the melt-blown technique, included: scanning electron microscopy (SEM), UV/Vis transmittance, FTIR spectrometry, and air permeability. The nonwovens were subjected to microbial activity tests against colonies of Gram-positive (Staphylococcus aureus) and Gram-negative (Escherichia coli) bacteria. Results indicate that the described nonwovens can be successfully used as an antibacterial material.
\end{abstract}

Keywords: poly(propylene); nonwoven fabric; Alafosfalin; antibacterial activity; polymer functionalization; polyolefins

\section{Introduction}

Poly(propylene) nonwoven (PP nonwoven) fabric is a thermoplastic, small density material with excellent comprehensive performance, mildew resistant, with a great development potential as medical materials [1]. Thus, PP nonwoven fabrics are applied as containers, suture material and surgical meshes, oxygenator membranes [2], or wound dressings [3,4]. In order to expand the functions of PP nonwoven fabrics to medical requirements, it is necessary to modify and process it. In this regard, biocompatible hybrids carrying and releasing bioactive drugs in a controlled and sustained manner may significantly improve the efficacy of wound therapies compared with current treatments. Antibacterial polypropylene nonwoven is often used as a hybrid material combining the PP nonwoven with other antibacterial components.

The recent, more representative examples of antibacterial PP nonwoven are listed in Table 1.

Table 1. Antibacterial polypropylene nonwoven.

\begin{tabular}{cccc}
\hline Abbrev. & Action/Application & Tested Bacteria & Ref. \\
\hline $\begin{array}{c}\text { PP-NIPAAm-Cg-Cs } \\
\text { PP-g-AA-Cg-Cs }\end{array}$ & Membrane-wound healing enhancement & S. aureus & {$[5]$} \\
\hline $\begin{array}{c}\text { PP-g-AA-Cs-Cg } \\
\text { PP-g-AA-Cs-Cg-Hi }\end{array}$ & Various concentrations of heparin & S. aureus & {$[6]$} \\
\hline $\begin{array}{c}\text { PP-AAg-Cg-Cs } \\
\text { PP-g-AA-PG-Cs }\end{array}$ & $\begin{array}{c}\text { Anti-bacterial property and the effect on } \\
\text { accelerating wound healing strong }\end{array}$ & S. aureus & {$[7,8]$} \\
\hline
\end{tabular}


Table 1. Cont.

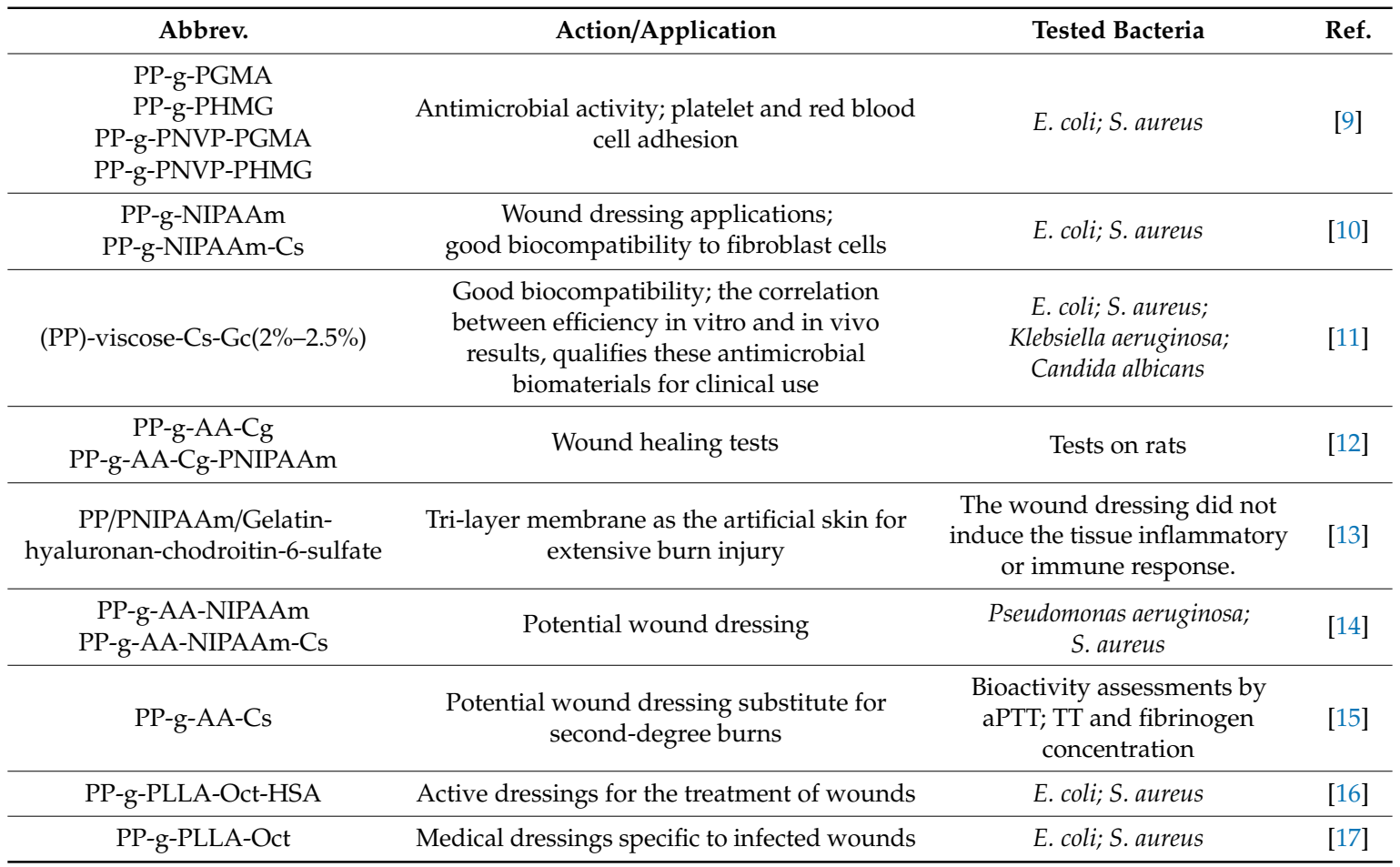

AA—acrylic acid; Cg-collagen; Cs—chitosan; GMA—glycidyl methacrylate (GMA); HMG-Hexamethylenediamine guanidine hydrochloride; Gc-gentamycine chloride; g-grafted; H-heparin NIPAAm-N-isopropyl acrylamide; NVP-N-Vinyl-2-pyrrolidone; Oct-octenidine; PLLA—poly(L-lactide); PP_polypropylene nonwoven; aPTT-activated partial thromboplastin time.

Bioactivity assessments on the chitosan-immobilized surfaces were anticipated by activated partial thromboplastin time (aPTT), thrombin time (TT), and fibrinogen concentration.

Aminophosphonic acids-phosphonic analogs of naturally occurring amino acids (Figure 1) present a power biological activity, being inhibitors of native amino acid enzymes. The significance of aminophosphonates is illustrated by the multidirectionality of the studies conducted on them: methods of synthesis of aminophosphinic acids $\left(\mathrm{AA}^{\mathrm{PH}}\right)$, aminophosphonic acids $\left(\mathrm{AA}^{\mathrm{P}}\right)$ and phosphonopeptides(P-terminal $\left(\mathrm{AA}^{\mathrm{C}}-\mathrm{AA}^{\mathrm{P}}\right)$ and $\mathrm{N}$-terminal $\left(\mathrm{AA}^{\mathrm{P}}-\mathrm{AA}{ }^{\mathrm{C}}\right)$ ), occurrence in living matter (e.g., $\beta$-Ala ${ }^{\mathrm{P}}$ ), biological, pharmacological, industrial and agrochemical properties/applications [18-27].<smiles>[R]C([NH3+])C(=O)O</smiles>

AA<smiles>[R]C([NH3+])P(=O)([O-])O</smiles>

$A A^{P}$<smiles>[R]C([NH3+])[PH2](=O)[O-]</smiles>

$A A^{P(H)}$

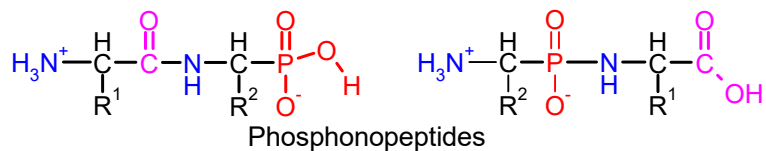
$A A^{C}-A A^{P}$ $A A^{P}-A A^{C}$

Figure 1. Structures of 1-amino carboxylic acids (AA), 1-aminophosphinic acids $\left(\mathrm{AA}^{\mathrm{P}(\mathrm{H})}\right)$, 1-aminophosphonic acids $\left(\mathrm{AA}^{\mathrm{P}}\right)$, phosphonopeptides:P-terminal $\left(\mathrm{AA}^{\mathrm{C}}-\mathrm{AA}^{\mathrm{P}}\right)$ and $\mathrm{N}$-terminal $\left(\mathrm{AA}^{\mathrm{P}}-\mathrm{AA}^{\mathrm{C}}\right)$ (applied names are in accordance with the general rules elaborated by Kudzin et al. [27,28]).

Aminophosphonate compounds of special biological importance are presented in Table 2.

Table 2. Aminophosphonate compounds of special biological importance.

\begin{tabular}{|c|c|c|c|}
\hline Abbrev. (Name) & Structure & Action/Application & Ref. \\
\hline Gly $^{\mathrm{P}}$ (phosphoglycine) & $\begin{array}{c}\mathrm{N}^{+}-\mathrm{O}_{\mathrm{II}}^{\mathrm{C}}-\stackrel{\mathrm{P}}{\mathrm{P}}-\mathrm{C} \\
\mathrm{H}_{2} \mathrm{O}^{-}\end{array}$ & $\begin{array}{l}\text { Primary degradation product of glyphosate, } \\
\text { inhibitor of prostate cancer cell growth in vitro, } \\
\text { phytotoxin }\end{array}$ & [18,29-33] \\
\hline
\end{tabular}


Table 2. Cont.

\begin{tabular}{|c|c|c|c|}
\hline Abbrev. (Name) & Structure & Action/Application & Ref. \\
\hline $\begin{array}{c}\beta \text {-Ala }{ }^{\mathrm{P}} \\
\text { ( } \beta \text {-phosphono-alanine, } \\
\text { 2-AEP, ciliatine) }\end{array}$ & 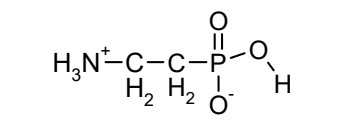 & $\begin{array}{c}\text { The most widespread, first } \mathrm{AA}^{\mathrm{P}} \text { isolated in } \\
\text { natural sources }\end{array}$ & {$[18,34-36]$} \\
\hline $\begin{array}{c}\text { Glu }{ }^{\gamma \mathrm{P}(\mathrm{Me})} \\
\text { (phosphinothricin, } \mathrm{PPT} \text { ) }\end{array}$ & 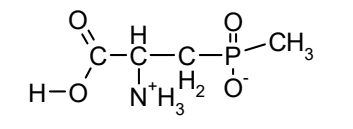 & $\begin{array}{l}\text { A naturally occurring broad-spectrum systemic } \\
\text { herbicide produced by several species of } \\
\text { Streptomyces; inhibiting glutamine synthetase }\end{array}$ & {$[18,37]$} \\
\hline $\begin{array}{c}\text { PMG } \\
\text { (PhosphonoMethyl-Glycine; } \\
\text { Glyphosate) }\end{array}$ & 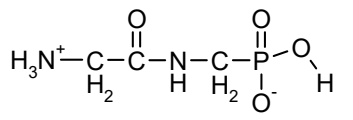 & $\begin{array}{c}\text { A broad spectrum, non-selective systemic } \\
\text { herbicide, inhibiting the activity of } \\
\text { 5-enolpyruvyl-shikimic acid-3-phosphate synthase }\end{array}$ & {$[18,38,39]$} \\
\hline $\begin{array}{c}\text { Ala-Ala }{ }^{\mathrm{P}} \\
\text { (alaphosphin; alafosfalin) }\end{array}$ & 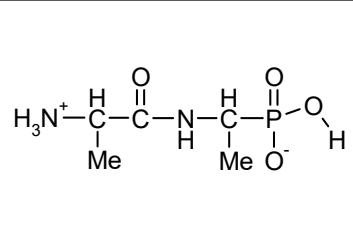 & $\begin{array}{l}\text { Ala-Ala }{ }^{\mathrm{P}} \text { selectively inhibited peptidoglycan } \\
\text { biosynthesis in both Gram-negative and } \\
\text { Gram-positive bacteria. The mechanism of action } \\
\text { of Ala-Ala }{ }^{\mathrm{P}} \text { involve three stages: (i) active } \\
\text { transport by peptide permeases; (ii) intracellular } \\
\text { peptidase cleavage; and (iii) action of Ala-Ala }{ }^{\mathrm{P}} \text { on } \\
\text { alanine racemase (EC 5.1.1.1) }\end{array}$ & {$[18,40-49]$} \\
\hline & ance with $t$ & eral rules elaborated by Kudzin et al. [24,25]. & \\
\hline
\end{tabular}

Alafosfalin((S)-Alanyl-(R)-1-aminoethylphosphonic acid) the representative of phosphonopeptides, is a bioactive compound with high antibacterial properties [40-49]. Thus, presented for a wide spectrum of Gram-positive and Gram-negative bacteria. Thus minimum inhibitory concentrations (MIC) in vitro of Alafosfalin against representative bacteria, (Enterobacter species 1398; Enterococcus faecalis O-G FS 5; E. coli NCBI 33; Haemophilusinfluenzae NCTC 4560; Klebsiella aerogenes O-G KA1 Serratia marcescens ATCC 14756; and Salmonella typhimurium) were determined by Atherton et al. [42].

Alafosfalin was selected from a range of related peptides on the basis of its activity, low toxicity in mammals, pharmacokinetic properties and stability to peptidases [40,44-47]. Alaphosphin proved active against majority of Serratiamarcescens strains [48], and also in vitro potentiation of cephalosporins against urinary tract bacteria [49] possessing potential usefulness in human medicine for the treatment of urinary tract of bacterial infections.

Despite the large range of applications of aminophosphonate compounds, there is only a Blanchard and Graves paper on their usage as cellulose hybrids [50].

As a part of our research program directed on the synthesis of biologically active functionalized phosphonates $[26,27,51-53]$ and their grafting on polymer matrix [54] we present the preparation and biological exploration of a polymer hybrid, based on polypropylene (PP) nonwoven fabric modified on surface by representative P-terminal phosphonopeptide-Alafosfalin (Alaphosphin).

\section{Materials and Methods}

\subsection{Materials}

\subsubsection{Polymers}

Polypropylene (PP) produced by Borealis (Vienna, Austria) type HL612 FB, MFR = $1200 \mathrm{~g} / 10 \mathrm{~min}$, in the form of granulates was used for fabrication of nonwoven samples.

\subsubsection{Chemical Agents}

Alafosfalin (L-Alanyl-L-1-aminoethylphosphonic acid), Synonym: (S)-Alanyl-(R)-1-aminoethylphosphonic acid; Alaphosphin; L-Ala-Ala ${ }^{\mathrm{P}}$, CAS Number: 60668-24-8, $\geq 98.0 \%$ ) from Sigma-Aldrich (Saint Louis, MO, USA) was used for surface modification of polymer nonwovens. 


\subsubsection{Finishing Agents}

Revacryl 247-styrene-acrylic ester copolymer dispersion of low viscosity (Synthomer, Essex, UK); Lutexal Thickener HC-polyacrylate, ammonia salt (BASF, Ludwigshafen, Germany) as thickening agent;Pluriol 600-poly(ethylene glycol) of molar mass $600 \mathrm{~g} / \mathrm{mol}$ (BASF) as wetting agent.

\subsubsection{Bacterial Strains}

E. coli (ATCC 25922) and S. aureus (ATCC 6538) were purchased from Microbiologics (St. Cloud, $\mathrm{MN}, \mathrm{USA})$.

\subsection{Methods}

\subsubsection{Nonwoven Fabrics}

Nonwovens were fabricated by the melt-blown technique using a one-screw laboratory extruder (Axon, Nyvang, Sweden) with a head with 30 holes of $0.35 \mathrm{~mm}$ diameter each, compressed air heater and collecting drum. Processing parameters for fabrication of PP nonwoven are presented in Table 3.

Table 3. Processing parameters applied for preparation of poly(propylene) (PP) composite nonwovens by melt-blown technique.

\begin{tabular}{cc}
\hline \multicolumn{2}{c}{ Processing Parameters } \\
\hline Temperature of the extruder in zone 1 & $240{ }^{\circ} \mathrm{C}$ \\
Temperature of the extruder in zone 2 & $285^{\circ} \mathrm{C}$ \\
Temperature of the extruder in zone 3 & $290^{\circ} \mathrm{C}$ \\
Head temperature & $240{ }^{\circ} \mathrm{C}$ \\
Air heater temperature & $270{ }^{\circ} \mathrm{C}$ \\
Air flow rate & $7-8 \mathrm{~m}^{3} / \mathrm{h}$ \\
Polymer yields & $4 \mathrm{~g} / \mathrm{min}$ \\
Mass per unit area of nonwovens & $80 \mathrm{~g} / \mathrm{m}^{2}$ \\
\hline
\end{tabular}

\subsubsection{Dip-Coating of Nonwoven Fabric and Modification of Phosphonodipeptide}

The coating pastes of homogeneous dispersion and appropriate viscosity (about 60-70 dPas) were prepared based on styrene-acrylic resin, wetting agent as well as thickening agent and water.

Thickening agent ensures viscosity and appropriate grip of product, wetting agent prevents the formation of agglomerates in coating paste and uniformity in coating dispersion, and styrene-acrylic resin combines all ingredients of coating paste with nonwoven fabric. The applied ratio of component composition has main influence on the mechanical properties of the textile material.

Alafosfalin powder was added into the paste in 5 variants of concentrations: $0.005 \%, 0.01 \%, 0.05 \%$, $0.1 \%$, and $0.15 \%$ and then mixed for $10 \mathrm{~min}$. The nonwoven samples were impregnated with the paste, squeezed and dried for $3 \mathrm{~h}$ at $50{ }^{\circ} \mathrm{C}$ (to constant weight). The increase of sample dry mass after modification was 5\%. Component composition of used pastes is listed in Table 4.

Table 4. Component composition of used pastes (\%).

\begin{tabular}{cccc}
\hline Styrene-Acrylic Resin & Wetting Agent & Thickening Agent & Water \\
\hline $5 \mathrm{~g}$ & $5 \mathrm{~g}$ & $1 \mathrm{~g}$ & $89 \mathrm{~g}$ \\
$5 \%$ & $5 \%$ & $1 \%$ & $89 \%$ \\
\hline
\end{tabular}

\subsubsection{Scanning Electron Microscopy}

The microscope analysis (SEM) was performed on a TESCAN VEGA 3 scanning electron microscope (Brno, Czech Republic). The SEM microscopic examination of the surface topography was carried out in a high vacuum using the energy of the probe beam $20 \mathrm{ekV}$. The surface of each preparation was 
sprayed with a conductive substance (gold), using a Quorum Technologies Ltd. (Lewes, UK) vacuum dust extractor. Magnification 5000× and 10,000×.

\subsubsection{ATR-FTIR}

Changes of the chemical structure of polypropylene surface products were assessed using ATR-FTIR spectroscopy. The study was performed in the range of $400-4000 \mathrm{~cm}^{-1}$ using a spectrometer Jasco 4200 series with ATR attachment (Pike Gladi ATR, Fitchburg, WI, USA).

\subsubsection{UV-Vis Analysis}

Changes of the physical properties as transmittance $(\% T)$ of nonwoven polypropylene fabric before and after phosphonodipeptide incorporation were assessed using a double beam Jasco V-550 UV/Vis spectrophotometer (Tokyo, Japan) with integrating sphere attachment in the range: $200-800 \mathrm{~nm}$.

\subsubsection{Filtration Parameters}

Air permeability was determined for one layer of nonwoven sample and the test based on EN ISO 9237:1998 standard [55]. An FX 3300 TEXTEST AG permeability tester (Schwerzenbach, Switzerland) was used. Air at a pressure of 100 and $200 \mathrm{~Pa}$ was passed through a fabric area of $20 \mathrm{~cm}^{2}$ diameter for testing. An average of 10 values was taken to be the final value of the sample.

\subsubsection{Tensile Testing}

Tensile testing of nonwoven fabrics was carried out in accordance with the EN ISO 10319:2015-08 standard [56]. A Tinius Olsen H50KS tester (Horsham, PA, USA) was used. Stretching speed was $20 \mathrm{~mm} / \mathrm{min}$.

\subsubsection{Antimicrobial Activity}

The antibacterial activity of the resulting nonwoven fabrics was tested according to PN-EN ISO 20645:2006 [57] (textile fabrics-determination of antibacterial activity-agar diffusion plate test).

Gram-negative bacteria E. coli (ATCC 25922) and Gram-positive bacteria S. aureus (ATCC 6538) were used as model bacteria in this study.

Antibacterial activity of PP/Ala-AlaP hybrids was tested by the agar diffusion method using Muller Hinton medium agar. The test was initiated by pouring each agar onto sterilized Petri dishes and allowing it to solidify. The surface of the growth media was inoculated by overnight broth cultures of bacteria $\left(0.4 \times 10^{8} \mathrm{CFU} \mathrm{mL}{ }^{-1}\right)$. Samples of sterile PP discs $(10 \mathrm{~mm})$ were charged with coating pastes with various amounts of Ala-Ala ${ }^{\mathrm{P}}$ (Table 5) and then discs with hybrids Ala-Ala ${ }^{\mathrm{P}} / \mathrm{PP}$ were placed onto the inoculated agar and incubated at $37^{\circ} \mathrm{C}$ for $24 \mathrm{~h}$. The diameter of the clear zone around the sample was measured as an indication of growth inhibition. All tests were carried out in duplicate. Simultaneously, the same tests were carried out as control samples with samples of unmodified polypropylene nonwoven.

\section{Results and Discussion}

The analysis of the biofunctionalized nonwoven fabrics covered: scanning electron microscopy (SEM), UV/Vis transmittance, ATR-FTIR spectrometry, and also technical parameters, including filtration parameters and tensile properties (durability for stretching and relative elongation). For samples with the highest charge with Ala-Ala ${ }^{\mathrm{P}}$, an antimicrobial activity against representative Gram-positive and Gram-negative bacteria was determined.

\subsection{Scanning Electron Microscopy}

Scanning electron microscopy SEM spectra of polypropylene nonwoven (PP) and polypropylene nonwoven charged with phosphonodipeptide modifier (alafosfalin paste concentrations $0.15 \%$ ) are 
presented in Figure 2. SEM spectra of polypropylene nonwoven present smooth surface of unmodified polymer fibers. The modification of PP by a surface deposition of Ala-Ala ${ }^{\mathrm{P}}$ lead to a rough surface of the textile, covered with dots/smudges of the modifier on PP fibers, accompanied by formation of more loose texture of the modified nonwoven.

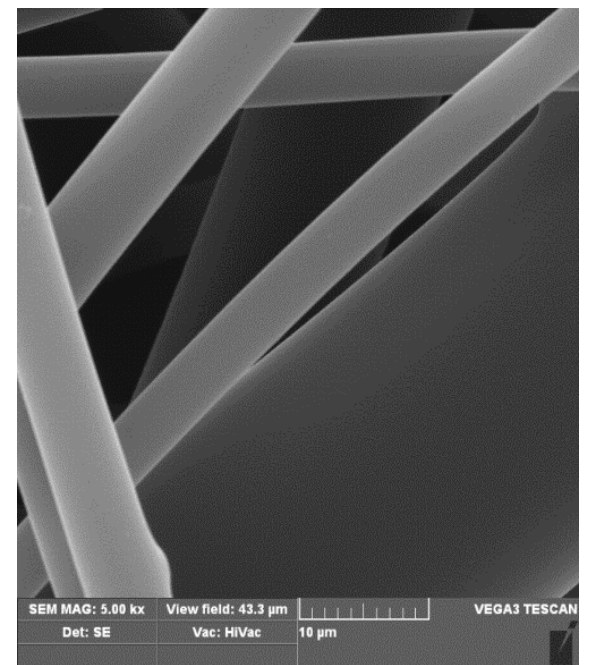

(a)

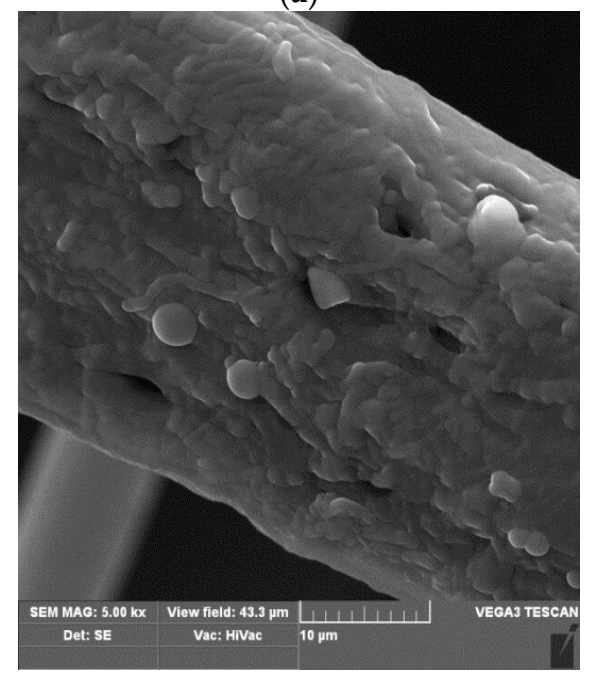

(c)

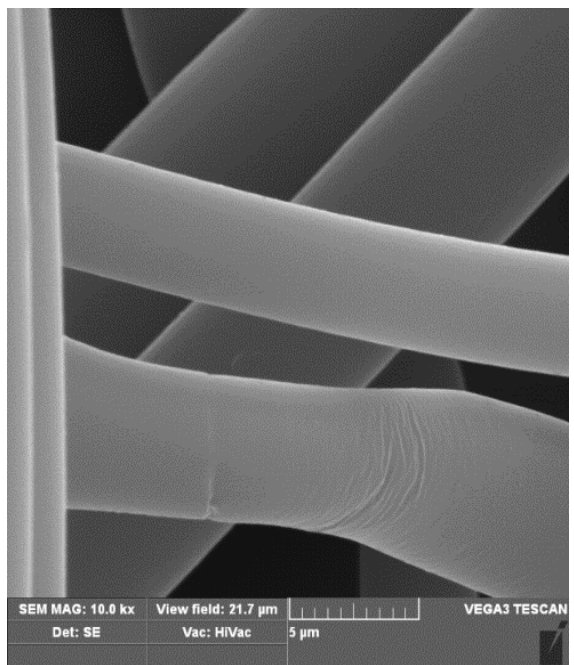

(b)

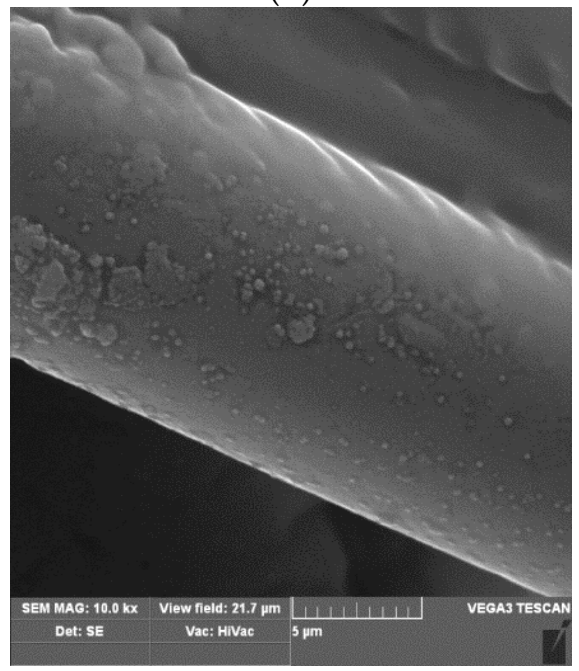

(d)

Figure 2. SEM spectra of polypropylene nonwoven (PP) $(\mathbf{a}, \mathbf{b})$ and polypropylene nonwoven with phosphonodipeptide modifier $(\mathbf{c}, \mathbf{d})$, taken at magnifications $5.00 \mathrm{k} \times\left(5 \times 10^{4}\right)($ left $)$ and $10.0 \mathrm{k} \times\left(10 \times 10^{4}\right)$ (right), respectively.

\subsection{ATR-FTIR Spectra}

Comparison of ATR-FTIR spectra of Ala-Ala ${ }^{\mathrm{P}}$, polypropylene nonwoven (PP), and polypropylene nonwoven charged with Ala-Ala ${ }^{\mathrm{P}}\left(\mathrm{Ala}-\mathrm{Ala}{ }^{\mathrm{P}} / \mathrm{PP}\right)$ is presented on Figure 3.

Characteristic FTIR signals of Ala-Ala ${ }^{\mathrm{P}}$, polypropylene (PP) and Ala-Ala ${ }^{\mathrm{P}}$-polypropylene nonwoven hybrid (PP/Ala-Ala $\left.{ }^{\mathrm{P}}\right)$ are summarized in Table 5.

Thus, the IR spectrum of Ala-Ala ${ }^{\mathrm{P}} / \mathrm{PP}$ hybrid (Ala-Ala ${ }^{\mathrm{P}}$ paste concentrations $0.15 \%$ ) reveals the bands derived from representative bands of Ala-Ala ${ }^{\mathrm{P}}$, namely bands at $3273 \mathrm{~cm}^{-1}(v(\mathrm{~N}-\mathrm{H})), 1664 \mathrm{~cm}^{-1}$ (characteristic for $v(\mathrm{C}=\mathrm{O}), v(\mathrm{C}-\mathrm{N})_{\mathrm{A}}, \delta\left(\mathrm{CC}_{\mathrm{A}}(=\mathrm{O}) \mathrm{N}_{\mathrm{A}}\right), 1081 \mathrm{~cm}^{-1}\left(v(\mathrm{C}-\mathrm{N}), v(\mathrm{C}-\mathrm{C})_{\mathrm{Ala}}, \delta\left(\mathrm{C}_{\mathrm{CH}_{3}}\right)_{\mathrm{Ala}}\right.$, $\left.\rho_{\mathrm{b}}\left(\mathrm{C}-\mathrm{N}^{+} \mathrm{H}_{3}\right)\right), 930 \mathrm{~cm}^{-1}\left(\left(\delta(\mathrm{C}-\mathrm{C})_{\text {Ala }}, v\left(\mathrm{C}-\mathrm{N}^{+} \mathrm{H}_{3}\right)\right) ; 700 \mathrm{~cm}^{-1}\left(\nu\left(\mathrm{C}_{\mathrm{S}}-\mathrm{P}\right), v\left(\mathrm{C}-\mathrm{C}_{\mathrm{A}}\right)\right)\right.$ and $558 \mathrm{~cm}^{-1}$ $\left(\delta\left(\mathrm{N}_{\mathrm{A}} \mathrm{C}_{\mathrm{S}}(\mathrm{P}) \mathrm{C}\right) \delta\left(\mathrm{N}_{\mathrm{A}} \mathrm{C}_{\mathrm{S}}(\mathrm{P}) \mathrm{C}\right)\right)$, respectively. 


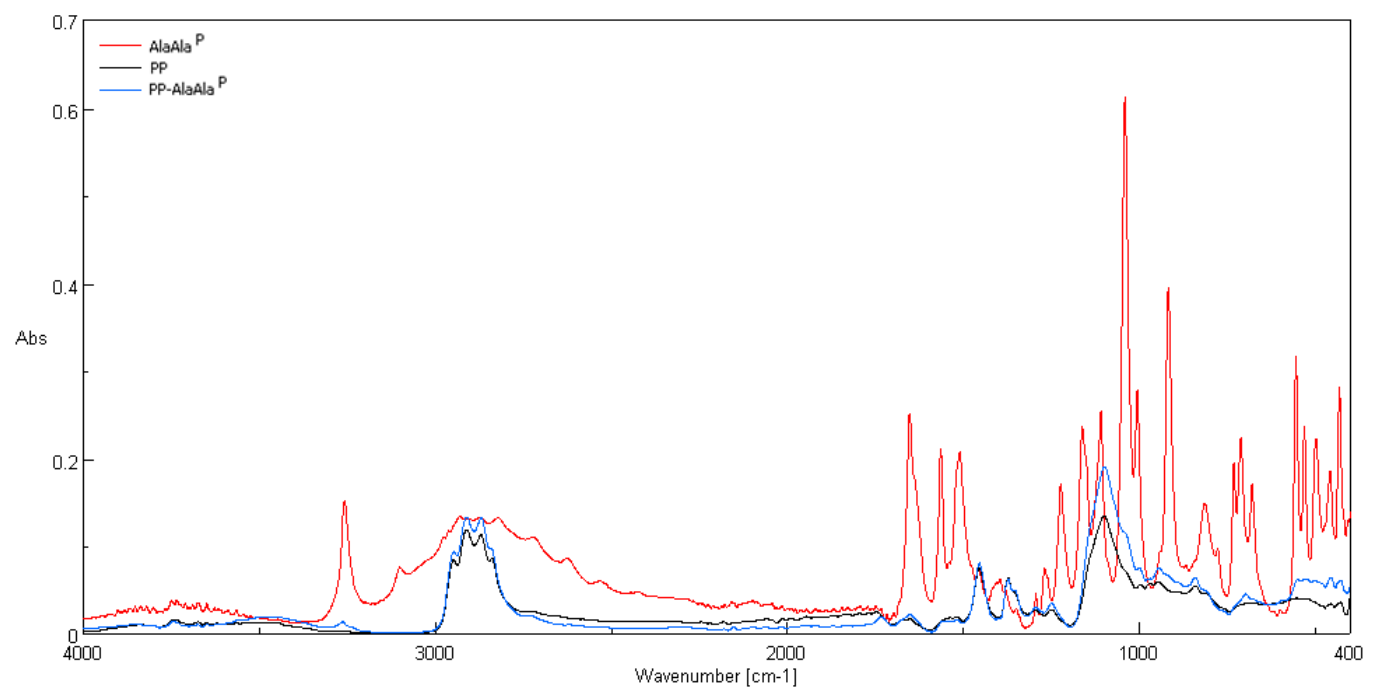

Figure 3. ATR-FTIR spectra of Ala-Ala ${ }^{\mathrm{P}}$, polypropylene nonwoven (PP), and nonwoven sample charged with Ala-Ala ${ }^{\mathrm{P}}(0.15 \%)$ (PP/Ala-AlaP).

Table 5. Characteristic FTIR bands determined for Ala-Ala ${ }^{\mathrm{P}}$, polypropylene (PP), and Ala-AlaP polypropylene nonwoven hybrid (PP/Ala-Ala $\left.{ }^{\mathrm{P}}\right)$.

\begin{tabular}{|c|c|c|c|c|c|c|c|c|c|}
\hline \multicolumn{10}{|c|}{ Polypropylene-IR according to Urbaniak-Domagala, 2012 [58] } \\
\hline \multicolumn{10}{|c|}{ Vibrations } \\
\hline $\begin{array}{c}\text { Wave number } \\
\left(\mathrm{cm}^{-1}\right)\end{array}$ & 2916 & 2959 & 2881 & 2841 & 1460 & 1376 & 1357 & $\begin{array}{l}1170, \\
1153\end{array}$ & $\begin{array}{l}975, \\
899\end{array}$ \\
\hline $\begin{array}{l}\text { Vibration type } \\
\text { (group) }\end{array}$ & $v\left(\mathrm{CH}_{2}\right)$ & $v\left(\mathrm{CH}_{3}\right)$ & $v\left(\mathrm{CH}_{3}\right)$ & $v\left(\mathrm{CH}_{2}\right)$ & $\delta\left(\mathrm{CH}_{3}\right)$ & $\delta\left(\mathrm{CH}_{3}\right)$ & $\gamma\left(\mathrm{CH}_{2}-\mathrm{CH}\right)$ & $\begin{array}{l}\gamma\left(\mathrm{CH}_{3}\right), \\
\delta\left(\mathrm{CH}_{2}\right), \\
\delta(\mathrm{CH})\end{array}$ & $\begin{array}{c}\gamma\left(\mathrm{CH}_{3}\right) \\
v\left(\mathrm{CH}_{2}\right), v(\mathrm{CH})\end{array}$ \\
\hline
\end{tabular}

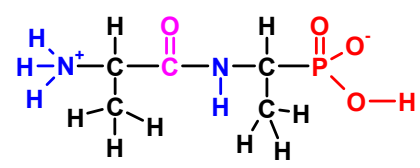

\begin{tabular}{|c|c|c|c|c|c|c|c|c|c|}
\hline \multicolumn{10}{|c|}{ Vibrations } \\
\hline $\begin{array}{l}\text { Wave number, } \\
\left(\mathrm{cm}^{-1}\right)\end{array}$ & 3273 & 3100 & 2982 & $\begin{array}{l}2940 \\
2885\end{array}$ & 1664 & 1081 & 930 & 700 & 558 \\
\hline $\begin{array}{l}\text { Vibration type } \\
\text { (group) }\end{array}$ & $v(\mathrm{~N}-\mathrm{H})$ & $v(\mathrm{C}-\mathrm{H})$ & $v\left(\mathrm{C}_{\mathrm{S}}-\mathrm{H}\right)$ & $v(\mathrm{C}-\mathrm{H}) \mathrm{CH}_{3}$ & $\begin{array}{c}v(\mathrm{C}=\mathrm{O}) \\
v(\mathrm{C}-\mathrm{N})_{\mathrm{A}} \\
\Delta\left(\mathrm{CC}_{\mathrm{A}}(=\mathrm{O}) \mathrm{N}_{\mathrm{A}}\right)\end{array}$ & $\begin{array}{c}v(\mathrm{C}-\mathrm{N}) \\
v(\mathrm{C}-\mathrm{C})_{\mathrm{Ala}} \\
\delta\left(\mathrm{C}_{\mathrm{CH}}\right)_{\mathrm{Ala}} \\
\rho_{\mathrm{b}}\left(\mathrm{C}-\mathrm{N}^{+} \mathrm{H}_{3}\right)\end{array}$ & $\begin{array}{c}\delta(\mathrm{C}-\mathrm{C})_{\mathrm{Ala}} \\
v\left(\mathrm{C}-\mathrm{N}^{+} \mathrm{H}_{3}\right)\end{array}$ & $\begin{array}{l}v\left(\mathrm{C}_{\mathrm{S}}-\mathrm{P}\right) \\
v\left(\mathrm{C}-\mathrm{C}_{\mathrm{A}}\right)\end{array}$ & $\begin{array}{l}\Delta\left(\mathrm{N}_{\mathrm{A}} \mathrm{C}_{\mathrm{S}}(\mathrm{P}) \mathrm{C}\right) \\
\delta\left(\mathrm{N}_{\mathrm{A}} \mathrm{C}_{\mathrm{S}}(\mathrm{P}) \mathrm{C}\right)\end{array}$ \\
\hline \multicolumn{10}{|c|}{ Ala-Ala ${ }^{\mathrm{P}} / \mathrm{PP}$} \\
\hline $\begin{array}{l}\text { Vibration type } \\
\text { (group) }\end{array}$ & $v(\mathrm{~N}-\mathrm{H})$ & - & - & - & $\begin{array}{c}v(\mathrm{C}=\mathrm{O}) \\
v(\mathrm{C}-\mathrm{N})_{\mathrm{A}}^{\prime} \\
\Delta\left(\left(\mathrm{CC}_{\mathrm{A}}(=\mathrm{O}) \mathrm{N}_{\mathrm{A}}\right)\right.\end{array}$ & $\begin{array}{c}v(\mathrm{C}-\mathrm{N}) \\
v(\mathrm{C}-\mathrm{C})_{\mathrm{Ala}} \\
\delta\left(\mathrm{C}_{\mathrm{CH}}\right) \\
\rho_{\mathrm{b}}\left(\mathrm{C}-\mathrm{N}^{+} \mathrm{H}_{3}\right)\end{array}$ & $\begin{array}{c}\delta(\mathrm{C}-\mathrm{C})_{\mathrm{Ala}} \\
v\left(\mathrm{C}-\mathrm{N}^{+} \mathrm{H}_{3}\right)\end{array}$ & $\begin{array}{l}v\left(C_{S}-P\right) \\
v\left(C-C_{A}\right)\end{array}$ & $\begin{array}{l}\Delta\left(\mathrm{N}_{\mathrm{A}} \mathrm{C}_{\mathrm{S}}(\mathrm{P}) \mathrm{C}\right) \\
\delta\left(\mathrm{N}_{\mathrm{A}} \mathrm{C}_{\mathrm{S}}(\mathrm{P}) \mathrm{C}\right)\end{array}$ \\
\hline
\end{tabular}

Legend: $\gamma$-stretching vibration, $\delta$-deformation, $\rho \mathrm{b}$-bending deformation, $\gamma$-twisting vibrations, CA-the carbon atom of the amide bond, NA - the nitrogen atom of the amide bond, Cs-the carbon atom of the spacer group between alanine and phosphonate group, $\mathrm{CCH}_{3}$-the carbon atom of the methyl group, $\mathrm{CCOOH}$-the carbon atom of the carbonyl group, Ala-part of N-terminal alanine, and S-shoulder. 


\subsection{UV/Vis Transmittance Spectra}

Comparison of transmittance spectra $(\% \mathrm{~T})$ in the range $\lambda=200-800 \mathrm{~nm}$ of polypropylene nonwoven samples without $(\mathrm{PP})$ and with $\mathrm{L}-\mathrm{Ala}-\mathrm{Ala}{ }^{\mathrm{P}}$ modifier (PP-MOD-Ala-Ala ${ }^{\mathrm{P}}$ paste concentrations $0.15 \%$ ) is given in Figure 4. Recorded UV/Vis transmittance spectra (\%T) of samples after phosphonodipeptide modification revealed changes in macrostructure of nonwoven after modification expressed by the depress of transmittance ability in the range $\lambda=200-800 \mathrm{~nm}$. All polypropylene modified nonwoven samples with different L-Ala-Ala ${ }^{\mathrm{P}}$ contents had the similar spectral characteristics and transmittance.

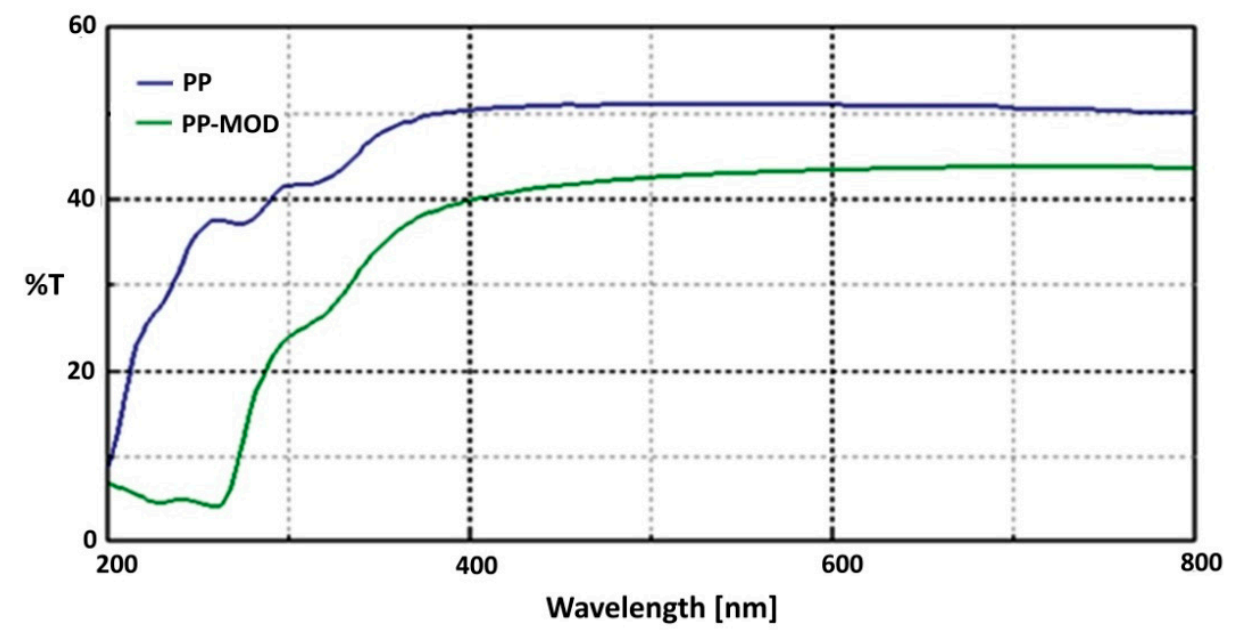

Figure 4. Comparison of transmittance spectra (\%T) in the range $\lambda=200-800 \mathrm{~nm}$ of polypropylene nonwoven samples without (PP) and with L-Ala-Ala ${ }^{\mathrm{P}}$ modifier (PP-MOD).

\subsection{Technical Parameters}

Filtration parameters expressed by the air permeability were detected for clean polypropylene nonwoven and nonwovens with addition of Alafosfalin. All these results indicated that phosphonodipeptide modification decreased filtration properties of nonwovens (Table 6). Modified nonwoven samples with different L-Ala-Ala ${ }^{\mathrm{P}}$ contents had an approximately similar result of filtration properties. The content of coating pastes L-Ala-Ala ${ }^{\mathrm{P}}$ applied on the polypropylene nonwoven samples does not affect filtration properties.

Table 6. The air flow resistance of polypropylene (PP) nonwovens without and with L-Ala-Ala ${ }^{\mathrm{P}}$ modifier according to: PN-EN ISO 9237:1998 [55].

\begin{tabular}{ccccccccc}
\hline \multirow{2}{*}{ Parameter } & & \multicolumn{5}{c}{ PP-Ala-Ala ${ }^{\mathbf{P}}$ (\%Ala-Ala ${ }^{\mathbf{P}}$ Paste Concentrations) } \\
\cline { 4 - 9 } & & $\mathbf{P P}$ & $\mathbf{0}$ & $\mathbf{0 . 5}$ & $\mathbf{1}$ & $\mathbf{5}$ & $\mathbf{1 0}$ & $\mathbf{1 5}$ \\
\hline Average air permeability & $100 \mathrm{~Pa}$ & 250 & 196 & 198 & 185 & 196 & 193 & 191 \\
$(\mathrm{~mm} / \mathrm{s})$, pressure decrease: & $200 \mathrm{~Pa}$ & 482 & 369 & 355 & 322 & 351 & 360 & 355 \\
\hline
\end{tabular}

The results of tensile strength testing, including durability for stretching $(\mathrm{kN} / \mathrm{m})$ and relative elongation at maximum load (\%) of PP nonwoven fabrics and PP/Ala-Ala ${ }^{\mathrm{P}}$ hybrids are listed in Table 7.

Table 7. Results of tensile strength test.

\begin{tabular}{cccccccc}
\hline \multirow{2}{*}{ Parameter } & \multirow{2}{*}{$\mathbf{P P}$} & \multicolumn{6}{c}{ PP-Ala-Ala $^{\mathbf{P}}$ (\%Ala-Ala } \\
\cline { 3 - 7 } & & $\mathbf{0}$ & $\mathbf{0 . 5}$ & $\mathbf{1}$ & $\mathbf{5}$ & $\mathbf{1 0}$ & $\mathbf{1 5}$ \\
\hline Tensile strength $(\mathrm{kN} / \mathrm{m})$ & 0.32 & 0.40 & 0.41 & 0.39 & 0.38 & 0.37 & 0.37 \\
$\begin{array}{c}\text { Relative elongation } \\
\text { at maximum load }(\%)\end{array}$ & 35.0 & 38.7 & 38.1 & 38.2 & 37.5 & 37.3 & 37.2 \\
\hline
\end{tabular}


The results revealed an increase of these parameters for PP loaded with the paste in comparison with $\mathrm{PP}$, namely distinct in tensile strength $(0.32$ to $0.40(\mathrm{kN} / \mathrm{m}))$ and slow in relative elongations $(35.0 \%$ to $38.7 \%)$, respectively.

\subsection{Antimicrobial Activity}

The nonwovens prepared were subjected to antimicrobial activity tests against E. coli (ATCC 25922) and S. aureus (ATCC 6538) [60,61] (Table 8). Results of these studies gave new Ala-Ala ${ }^{\mathrm{P}}$ biofunctionalized materials which provide antimicrobial protection against different bacterial microorganisms (Gram-negative and Gram-positive).

Table 8. Results of tests on the antibacterial activity of L-Ala-Ala ${ }^{\mathrm{P}}$ modified nonwovens.

\begin{tabular}{|c|c|c|c|}
\hline \multirow{2}{*}{ Sample No. } & \multirow{2}{*}{$\begin{array}{c}\text { Ala-Ala }{ }^{\mathrm{P}} \text { on Polypropylene Nonwovens } \\
{\left[\text { Ala-Ala }{ }^{\mathrm{P}} / \mathrm{PP}\right]} \\
\text { Ala-Ala }{ }^{\mathrm{P}} \text { Coating Pastes Concentrations (\%) }\end{array}$} & \multicolumn{2}{|c|}{$\begin{array}{c}\text { Average Inhibition Zone (ZoI) of } \\
\text { Bacterial Growth for Bacteria (mm) }\end{array}$} \\
\hline & & E. coli & S. aureus \\
\hline 1 & 0 & 0 & 0 \\
\hline 2 & 0.005 & 0 & 0 \\
\hline 3 & 0.01 & 12 & 0 \\
\hline 4 & 0.05 & 12 & 12 \\
\hline 5 & 0.1 & 14 & 14 \\
\hline 6 & 0.15 & 14 & 14 \\
\hline Concent & $\begin{array}{l}\text { Surface of applied disks with } 1 \mathrm{~cm} \text { diamet } \\
\text { a of inoculum (bacterial suspension) amount }\end{array}$ & $\begin{array}{l}\text { equals } 0.78 \\
\text { live bacteri }\end{array}$ & $=0.4 \times 10^{8}$ \\
\hline
\end{tabular}

Amounts of $0.01 \%$ Ala-Ala ${ }^{\mathrm{P}}$ coating paste concentration sapplied on polypropylene nonwovens provide antimicrobial properties for $E$. coli and no less than $0.05 \%$ phosphonodipeptide modification of PP nonwoven showed antibacterial activity against $\mathrm{S}$. aureus (Table 8). At the same time, applied surface modification of the nonwovens with phosphonopeptide had no effect on mechanical properties of the modified textile.

\section{Conclusions}

The development of new products is closely related to progress in many areas of science, especially in chemistry and biochemistry. The interdisciplinary study focused on functionalization of textile polymers by an insertion (or coating) of bioactive compounds into/onto the surface of their fibers which can be an interesting direction of the textile product engineering development.

These new, described nonwovens can be successfully used as an antibacterial material. An important attribute of the presented solution is the simple process of implementation, low production costs and good efficiency of antimicrobial properties.

Apart from the antibacterial activity, such products also show acceptable air filtration ability and tensile strength, independently from the amounts of applied phosphonodipeptide surface concentrations.

The introduction of bioactive aminophosphonateclass (PCN compounds) into the structure of textiles is a novelty in the scientific literature, both in the modification of textiles and in the title compounds itself. Alafosfalin and other phosphonodipeptides compounds are characterized by uncomplicated synthesis and safety of use, for the above reasons there are large possibilities for wider use in the material and textile manufacturing industry.

Author Contributions: M.H.K. designed the research study and contributed to the data interpretation and to the manuscript drafting and revisions, analyzed the data and contributed to writing the manuscript. Z.M. analyzed the data and participated in the publication preparation. A.W. analyzed the data and participated in the publication preparation and J.S.-L. analyzed the data and participated in the publication preparation. 
Funding: This research was funded by the Polish Ministry of Science and Higher Education within statutory research work carried out at the The Lukasiewicz Research Network-Textile Research Institute, Lodz, Poland.

Conflicts of Interest: The authors declare no conflicts of interest.

\section{References}

1. Huang, K.S.; Lian, H.S.; Chen, J.B. Study on the modification of PP nonwoven fabric. Fibres Text. East. Eur. 2011, 3, 82-87.

2. Maitz, M.F. Applications of synthetic polymers in clinical medicine. Biosurf. Biotribol. 2015, 1, $161-176$. [CrossRef]

3. Rajendran, N.K.; Kumar, S.S.D.; Houreld, N.N.; Abrahamse, H. A review on nanoparticle based treatment for wound healing. J. Drug Deliv. Sci. Technol. 2018, 44, 421-430. [CrossRef]

4. Simoes, D.; Miguel, S.P.; Ribeiro, M.P.; Coutinho, P.; Mendonça, A.G.; Correia, I.J. Recent advances on antimicrobial wound dressing: A review. Eur. J. Pharm. Biopharm. 2018, 127, 130-141. [CrossRef]

5. Wang, C.C.; Su, C.H.; Chen, C.C. Water absorbing and antibacterial properties of $N$-isopropyl acrylamide grafted and collagen/chitosan immobilized polypropylene nonwoven fabric and its application on wound healing enhancement. J. Biomed. Mater. Res. A 2008, 84, 1006-1017. [CrossRef]

6. Wang, C.C.; Chen, C.C.; Chen, F.L.; Lin, N.-S. An improvement on water absorbing and permeating properties: Heparin immobilizing on acrylic acid-grafted and collagen/chitosan-immobilized wound dressing. J. Appl. Polym. Sci. 2008, 109, 1431-1438. [CrossRef]

7. Wang, C.C.; Su, C.H.; Chen, J.P.; Chen, C.C. An enhancement on healing effect of wound dressing: Acrylic acid grafted and gamma-polyglutamic acid/chitosan immobilized polypropylene non-woven. Mater. Sci. Eng. C 2009, 29, 1715-1724. [CrossRef]

8. Wang, C.C.; Chen, J.P.; Chen, C.C. An enhancement on water absorbing and permeating abilities of acrylic acid grafted and chitosan/collagen immobilized polypropylene non-woven fabric: Chitosan obtained from Mucor. Mater. Sci. Eng. C 2009, 29, 1133-1139. [CrossRef]

9. Xin, Z.; Du, S.; Zhao, C.; Chen, H.; Sun, M.; Yan, S.; Luan, S.; Yin, J. Antibacterial performance of polypropylene nonwoven fabric wounddressing surfaces containing passive and active components. Appl. Surf. Sci. 2016, 365, 99-107. [CrossRef]

10. Chen, K.S.; Ku, T.Y.A.; Lee, C.H.; Lin, H.R.; Lin, F.H.; Chen, T.M. Immobilization of chitosan gel with cross-linking reagent on PNIPAAm gel/PP nonwoven composites surface. Mater. Sci. Eng. C 2005, 25, 472-478. [CrossRef]

11. Simovic, L.M.; Skundric, P.D.; Kostic, M.M.; Tasic, G.M.; Kojic, Z.Z.; Milakovic, B.D.; Medovic, A.H. Efficiency and biocompatibility of antimicrobial textile material of broad spectrum activity. J. Appl. Polym. Sci. 2011, 120, 1459-1467. [CrossRef]

12. Chen, J.P.; Lee, W.L. Collagen-grafted temperature-responsive nonwoven fabric for wound dressing. Appl. Surf. Sci. 2008, 255, 412-415. [CrossRef]

13. Lin, F.H.; Tsai, J.C.; Chen, T.M.; Chen, K.S.; Yang, J.M.; Kang, P.L.; Wu, T.H. Fabrication and evaluation of auto-stripped tri-layer wound dressing for extensive burn injury. Mater. Chem. Phys. 2007, 102, 152-158. [CrossRef]

14. Yang, J.M.; Lin, H.T. Properties of chitosan containing PP-g-AA-g-NIPAAmbigraft nonwoven fabric for wound dressing. J. Membr. Sci. 2004, 243, 1-7. [CrossRef]

15. Tyan, Y.C.; Liao, J.D.; Lin, S.P. Surface properties and in vitro analyses of immobilized chitozan onto polepropylene non-wofen fabric surface using antenna-coupling microwave plasma. J. Mater. Sci. Mater. Med. 2003, 14, 775-781. [CrossRef]

16. Ivanova, T.V.; Baier, G.; Landfester, K.; Musin, E.; Al-bataineh, S.; Cameron, D.C.; Whittle, J.D.; Sillanpää, M. Attachment of poly(L-lactide) nanoparticles to plasma-treated non-woven polymer fabrics using inkjet printing. Macromol. Biosci. 2015, 15, 1274-1282. [CrossRef]

17. Ivanova, T.V.; Krumpolec, R.; Homola, T.; Musin, E.; Baier, G.; Landfester, K.; Cameron, D.C.; Černák, M. Ambient air plasma pre-treatment of non-woven fabrics for deposition of antibacterial poly(L-lactide) nanoparticles. Plasma Process. Polym. 2017, 14, 1600231. [CrossRef]

18. Kukhar, V.P.; Hudson, H.R. Aminophosphonic and Aminophosphinic Acids. Chemistry and Biological Activity; Wiley \& Sons Ltd.: Chichester, UK, 2000. 
19. Maier, L. Phosphoroorganic detergents. Chimia 1969, 23, 323-330.

20. Petrov, K.A.; Chauzov, V.A.; Erokhina, T.S. Aminoalky lorganophosphorus compounds. Russ. Chem. Rev. 1974, 43, 984. [CrossRef]

21. Rizkalla, E.N. Metal chelates of phosphonate-containing ligands. Rev. Inorg. Chem. 1983, 5, 223-304.

22. Sikorski, J.A.; Logush, E.W. Aliphatic carbon-phosphorus compound as herbicides. In Handbook of Organophosphorus Chemistry, 1st ed.; Engel, R., Ed.; Marcel Dekker Inc.: New York, NY, USA, 1992; pp. 751-800.

23. Neuzil, E.; Cassaigne, A. Natural compounds with biologic value containing a P-C bond and phosphonates. Expos. Annu. Biochim. Med. 1980, 34, 165-210.

24. Mucha, A.; Kafarski, P.; Berlicki, L. Remarkable potential of the $\alpha$-aminophosphonate/ phosphinate structural motif in medicinal chemistry. J. Med. Chem. 2011, 54, 5955-5980. [CrossRef]

25. Orsini, F.; Sello, G.; Sisti, M. Aminophosphonic acids and derivatives. Synthesis and biological applications. Curr. Med. Chem. 2010, 17, 264-289. [CrossRef]

26. Kudzin, Z.H.; Kudzin, M.H.; Drabowicz, J.; Stevens, C.V. Aminophosphonic acids-phosphorus analogues of natural amino acids. Part 1: Syntheses of $\alpha$-aminophosphonic acids. Curr. Org. Chem. 2011, 15, 2015-2071. [CrossRef]

27. Kudzin, M.H.; Kudzin, Z.H.; Drabowicz, J. Thioureidoalkylphosphonates in the synthesis of 1-aminoalkylphosphonic acids. The Ptc-aminophosphonate method. Arkivoc 2011, VI, 227-269. [CrossRef]

28. Drabowicz, J.; Jakubowski, H.; Kudzin, M.H.; Kudzin, Z.H. Nomenclature of aminoalkylphosphonic acids and derivatives. Evolution of the code system. Acta Biochim. Polon. 2015, 62, 139-150. [CrossRef]

29. Grandcoin, A.; Piel, S.; Baurès, E. AminoMethylPhosphonic acid (AMPA) in natural waters: Its sources, behavior and environmental fate. Water Res. 2017, 117, 187-197. [CrossRef]

30. Aparicio, V.C.; De Gerónimo, E.; Marino, D.; Primost, J.; Carriquiriborde, P.; Costa, J.L. Environmental fate of glyphosate and aminomethylphosphonic acid in surface waters and soil of agricultural basins. Chemosphere 2013, 93, 1866-1873. [CrossRef]

31. Parajuli, K.R.; Zhang, Q.; Liu, S.; You, Z. Aminomethylphosphonic acid and methoxyacetic acid induce apoptosis in prostate cancer cells. Int. J. Mol. Sci. 2015, 16, 11750-11765. [CrossRef]

32. Parajuli, K.R.; Zhang, Q.; Liu, S.; You, Z. Aminomethylphosphonic acid inhibits growth and metastasis of human prostate cancer in an orthotopicxenograft mouse model. Oncotarget 2016, 7, 10616-10626. [CrossRef]

33. Gomes, M.P.; Smedbol, E.; Chalifour, A.; Hénault-Ethier, L.; Labrecque, M.; Lepage, L.; Lucotte, M.; Juneau, P. Alteration of plant physiology by glyphosate and its by-product aminomethylphosphonic acid: An overview. J. Exp. Bot. 2014, 65, 4691-4703. [CrossRef]

34. Horiguchi, M.; Kandatsu, M. Isolation of 2-aminoethane phosphonic acid from rumen protozoa. Nature 1959, 184 (Suppl. 12), 901-902. [CrossRef]

35. Alhadeff, J.A.; Van Bruggen, J.T.; Daves, D., Jr. Biosynthetic studies on 2-aminoethylphosphonic acid in a mammalian (rat) system. Biochim. Biophys. Acta 1972, 286, 103-106. [CrossRef]

36. Tan, S.A.; Tan, L.G. Distribution of ciliatine (2-aminoethylphosphonic acid) and phosphonoalanine (2-amino-3-phosphonopropionic acid) in human tissues. Clin. Physiol. Biochem. 1989, 7, 303-309.

37. Watts, M. Glufosinate-Ammonium Monograph. 2008. Available online: http://www.pananz.net/wp-content/ uploads/2013/04/Glufosinate-monograph-12-Dec-2008.pdf (accessed on 18 June 2019).

38. Franz, J.E.; Mao, M.K.; Sikorski, J.A. Glyphosate: A Unique Global Herbicide; American Chemical Society: Washington, DC, USA, 1997.

39. Dill, G.M.; Sammons, R.D.; Feng, P.C.C.; Kohn, F.; Kretzmer, K.; Mehrsheikh, A.; Bleeke, M.; Honegger, J.L.; Farmer, D.; Wright, D.; et al. Glyphosate: discovery, development, applications, and properties. In Glyphosate Resistance in Crops and Weeds. History, Development and Management; Nandula, V.K., Ed.; JohnWiley \& Sons, Inc.: Hoboken, NJ, USA, 2010.

40. Allen, J.G.; Atherton, F.R.; Hall, M.J.; Hassal, C.H.; Holmes, S.W.; Lambert, R.W.; Nisbet, L.J.; Ringrose, P.S. Phosphonopeptides, a new class of synthetic antibacterial agents. Nature 1978, 272, 56-58. [CrossRef]

41. Allen, J.G.; Atherton, F.R.; Hall, M.J.; Hassall, C.H.; Holmes, S.W.; Lambert, R.W.; Nisbet, L.J.; Ringrose, P.S. Phosphonopeptides as antibacterial agents: Alaphosphin and related phosphonopeptides. Antimicrob. Agents Chemother. 1979, 15, 684-695. [CrossRef]

42. Atherton, F.R.; Hall, M.J.; Hassall, C.H.; Lambert, R.W.; Ringrose, P.S. Phosphonopeptides as antibacterial agents: Rationale, chemistry and structure-activity relationships. Antimicrob. Agents Chemother. 1979, 15, 677-683. [CrossRef] 
43. Atherton, F.R.; Hall, M.J.; Hassall, C.H.; Lambert, R.W.; Lloyd, W.J.; Ringrose, P.S. Phosphonopeptides as antibacterial agents: Mechanism of action of alaphosphin. Antimicrob. Agents Chemother. 1979, 15, 696-705. [CrossRef]

44. Allen, J.G.; Lees, L.J. Pharmacokinetics of alafosfalin, alone and in combination with cephalexin, in humans. Antimicrob. Agents Chemother. 1980, 17, 973-979. [CrossRef]

45. Atherton, F.R.; Hassall, C.H.; Lambert, R.W. Synthesis and structure-activity relationships of antibacterial phosphonopeptides incorporating (1-aminoethyl)phosphonic acid and (aminomethyl)-phosphonic acid. J. Med. Chem. 1986, 29, 29-40. [CrossRef]

46. Neuman, H.J. Recent developments in the field of phosphonic acid antibiotics. J. Antimicrob. Chemother. 1984, 14, 309-311. [CrossRef]

47. Lejczak, B.; Kafarski, P.; Sztajer, H.; Mastalerz, P. Antibacterial activity of phosphono dipeptides related to alafosfalin. J. Med. Chem. 1986, 29, 2212-2217. [CrossRef]

48. Traub, W.H. In vitro evaluation of alaphosphin (Ro 03-7008) against Serratiamarcescens. Chemotherapy 1980, 26, 103-110. [CrossRef]

49. Arisawa, M.; Ohshima, J.; Ohsawa, E.; Maruyama, H.B. In vitro potentiation of cephalosporins by alafosfalin against urinary tract bacteria. Antimicrob. Agents. Chemother. 1982, 21, 706-710. [CrossRef]

50. Blanchard, E.J.; Graves, E.E. Phosphorylation of cellulose with some phosphonic acid derivatives. Text. Res. J. 2003, 73, 22-26. [CrossRef]

51. Kudzin, Z.H.; Depczyński, R.; Andrijewski, G.; Drabowicz, J.; Łuczak, J. 1-(N-Acylamino)alkanephosphonates. Part IV. N-Acylation of 1-Aminoalkanephosphonic Acids. Pol. J. Chem. 2005, 79, 499-513.

52. Kudzin, Z.H.; Depczyński, R.; Kudzin, M.H.; Drabowicz, J. 1-(N-chloroacetylamino)alkylphosphonic acids-synthetic precursors of phosphonopeptides. Amino Acids 2008, 34, 163-168. [CrossRef]

53. Kudzin, Z.H.; Depczynski, R.; Kudzin, M.H.; Luczak, J.; Drabowicz, J. 1-(N-Trifluoroacetylamino) alkylphosphonic acids: Synthesis and properties. Amino Acids 2007, 33, 663-667. [CrossRef]

54. Kudzin, M.H.; Mrozińska, Z.; Urbaniak, P.; Drabowicz, J. Phosphorylation of cellulose. In Proceedings of the 20th International Symposium Advances in the Chemistry of Heteroorganic Compounds, Łódź, Poland, 23-24 November 2017; p. 130.

55. EN ISO 9237:1998-Textiles-Determination of the Permeability of Fabrics to Air; International Organization for Standardization: Geneva, Switzerland, 1998.

56. EN ISO 10319:2015-08-Geosynthetics-Wide-Width Tensile Test; International Organization for Standardization: Geneva, Switzerland, 2015.

57. EN ISO 20645:2006-Textile Fabrics-Determination of Antibacterial Activity-Agar Diffusion Plate Test; International Organization for Standardization: Geneva, Switzerland, 2006.

58. Urbaniak-Domagala, W. The use of the spectrometric technique FTIR-ATR to examine the polymers surface. In Advanced Aspects of Spectroscopy; Farrukh, M.A., Ed.; IntechOpen: Rijeka, Croatia, 2012; pp. 85-112.

59. Podstawka, E.; Andrzejak, M.; Kafarski, P.; Proniewicz, L.M. Comparison of adsorption mechanism on colloidal silver surface of alafosfalin and its analogs. J. Raman Spectrosc. 2008, 39, 1238-1249. [CrossRef]

60. Jiang, L.; Wang, F.; Han, F.; Prinyawiwatkul, W.; No, H.K.; Ge, B. Evaluation of diffusion and dilution methods to determine the antimicrobial activity of water-soluble chitosan derivatives. J. Appl. Microbiol. 2012, 114, 956-963. [CrossRef]

61. Balouiri, M.; Sadiki, M.; Ibnsouda, S.K. Methods for in vitro evaluating antimicrobial activity: A review. J. Pharm. Anal. 2016, 6, 71-79. [CrossRef]

(C) 2019 by the authors. Licensee MDPI, Basel, Switzerland. This article is an open access article distributed under the terms and conditions of the Creative Commons Attribution (CC BY) license (http://creativecommons.org/licenses/by/4.0/). 